\title{
OSOBE KOJE ĆE DOBITI DVOSTRUKU NAGRADU
}

\section{Sažetak}

Žudeći Allahovom, džš., zadovoljstvu i Džennetu vjernik svakodnevno radi $i$ izvršava ono što mu je naredeno $i$ kloni se onoga što je zabranjeno. U sklopu Allahove, džs.s., milosti prema Njegovim robovima je i to da se djela u islamu višestruko vrednuju, pa se za neka biva nagraden deset puta, za neka sedamdeset a za veličinu nagrade za neka djela zna samo Uzvišeni Allah.

Rad ima za cilj istaknuti specifićnost pojedinih djela i njihovih počinioca koji ce za to biti dvostruko nagradeni, kroz kur'ansko-hadiske tekstove. Od tih osoba su sljedbenici ranijih nebeskih knjiga koji povjeruju u Muhammedovo, s.a.v.s., poslanstvo, Poslanikove, s.a.v.s., suprugelmajke vjernika, oni koji traže znanje, učač Kur'ana koji pri tome ima poteškoću, onaj koji pomno slǘa hutbu, klanjač na lijevoj strani džamije, onaj koji predvodi džemata $i$ mujezini, onaj koji je klanjao sa tejemmumom pa obnovi svoj namaz kada nade vodu i ostali koji su u ovom radu spomenuti.

Svakako da je neizostavno bilo ovdje spomenuti šta najpoznatiji komentatori Kur'ana kažu o ajetima koji tretiraju ovu tematiku, poput Ibn Kesira, Kurtubija i drugih, kao i okoristiti se najpoznatijim komentarima hadiskih zbirki, i učenjacima koji su pisali na ovu temu, poput Imama Sujutija $i$ drugih.

Ključne riječi: dvostruka nagrada, vjernik, Džennet, dva puta, višsstruko nagraden.

\section{Uvod}

Specifičnost vjere islamu je između ostalog i u tome da sve što čovjek uradi od dobra na ovom svijetu, to će vidjeti i za to će biti nagrađen, a sve što uradi od lošeg i to će vidjeti i naći na Drugom svijetu, kada se bude polagao račun za ono što je učinjeno na dunjaluku. Allah, dž.š., u Kur'anu kaže:

\footnotetext{
${ }^{1}$ Islamski pedagoški fakultet u Bihaću.
} 


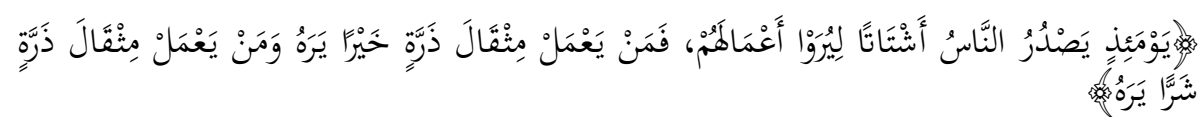

"Toga Dana ljudi će se odvojeno pojaviti da im se pokažu djela njihova: Onaj ko bude uradio koliko trun dobra - vidjet će ga, a onaj ko bude uradio i koliko trun zla- vidjet će ga." ${ }^{2}$

Koliko je ovaj ajet sadržajan govori naredna predaja:

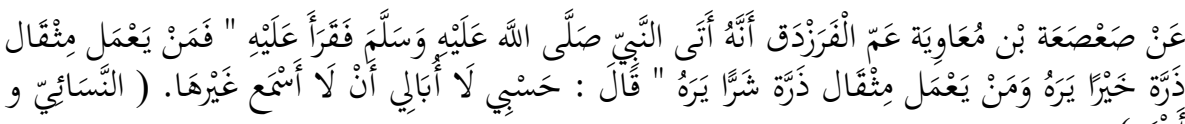

Jedan ashab po imenu Sa'sa' ibn Nadžije, amidža od El-Ferezdeka, r.a., je došao Allahovom Poslanuku, s.a.v.s., i proučio mu ove ajete: "Onaj ko bude uradio koliko trun dobra - vidjet će ga, a onaj ko bude uradio i koliko trun zla- vidjet će ga," pa je rekao: "Dovoljno mi je ovo da drugo ništa nisam čuo." ${ }^{3}$

Mnogo je hadisa koji govore o tome da ne treba potcjenjivati ni najmanje dobro djelo koje se učini, niti najmanji grijeh za koji se treba dogovarati. Za ovu priliku navest ćemo slijedeće hadise:

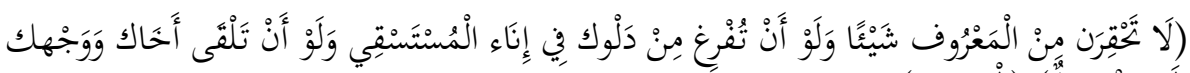

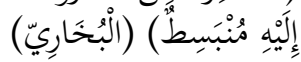

"Nipošto ne podcijeni učinjeno dobro, ma koliko sitno bilo; makar da uliješ kofu vode u sud onoga ko traži vodu, ili da svoga brata sretneš vedra i nasmijana lica."

Aiša, r.a., prenosi da joj je Poslanik, s.a.v.s., imao običaj reći:

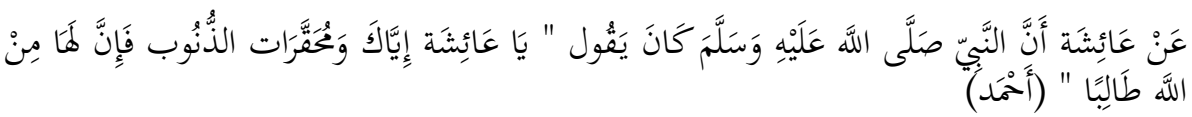

"Aiša, nipošto ne podcijeni sitne grijehe! I za njih će neko pred Allahom tražiti svoje pravo." ${ }^{5}$

\footnotetext{
${ }^{2}$ Kur'an, Ez-Zelzele, 5-7.

${ }^{3}$ Bilježe ga Nesai i Ahmed.

${ }^{4}$ Bilježi ga Buhari.

${ }^{5}$ Bilježi ga Ahmed.
} 
Kao što smo vidjeli u prethodnim tekstovima, čovjek će biti nagrađen za svako dobro koje je uradio a odgovarati će za svako loše djelo koje je učinio. Od Allahove, dž.š., neizmjerne milosti prema Njegovim robovima je da se dobra djela vrednuju i nagrađuju višestruko, neka po deset puta pa sve do sedam stotina puta, ili onoliko puta koliko zna samo Uzvišeni Allah, dok se za grijehe odgovora onoliko koliko su teški, bez uveličavanja kazne. To potvrđuje i naredna predaja od Ebu Seida, r.a., u kojoj mu Allahov Poslanik, s.a.v.s., kaže:

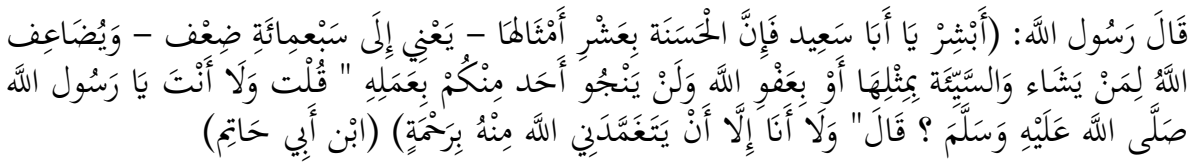

"Raduj se, o Ebu Seide, zaista se dobro djelo nagrađuje desetorostruko -pa i do sedam stotina puta- Allah, dž.š., će umnožavati kome hoće, a za loše djelo će se biti kažnjeno onoliko koliko je teško, ili će ga Allah, dž.š., oprostiti. A niko od vas se neće spasiti svojim djelima. Ebu Seid upita: -Pa zar ni ti, Allahov Poslaniče? On odgovori: -Neću ni ja osim da me Allah obaspe svojom milošću."6

U nekoliko kur'anskih ajeta i Pejgamberovih, s.a.v.s., hadisa su spomenute osobe koje će biti duplo nagrađene, imat će za svoja dobra djela udvostručenu nagradu. Kao i mnoge druge teme tako i ova tematika nije mašila naše vrijedne učenjake koji su o mnogo čemu pisali. Među najpoznatijim koji su o ovoj temi pisali bio je hafiz Dželuluddin Es-Sujuti -rahimehullah- koji je napisao posebnu knjižicu koju je nazvao: Metleul-bedrejni fimen ju'tevne edžrehum merretejni i ona mi je bila glavni orjentir $u$ pripremi ovog rada. Evo nekih ajeta $\mathrm{i}$ hadisa u kojima se spominju oni koji će imati dvostruku nagradu:

\section{Sljedbenici ranijih nebeskih knjiga koji povjeruju u Kur'an i u Muhammedovo, s.a.v.s., poslanstvo}

Poznati tabi'in, Seid ibn Džubejr je rekao: "Došlo je sedamnaest svećenika koje je poslao Negus, vladar Abesinije. Nakon što su došli kod Vjerovjesnika, s.a.vs., on im je proučio suru Jasin, dok nije završio, te su oni zaplakali i primili islam. U vezi s njima objavljeni su ovi ajeti:

\footnotetext{
${ }^{6}$ Bilježi ga Ibn Ebi-Hatim.
} 


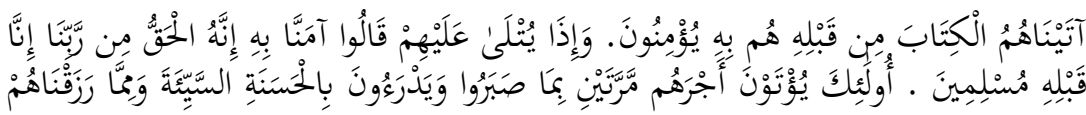

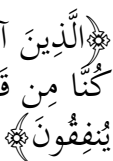

"Oni kojima smo dali Knjigu prije Kur'ana, vjeruju u nju, a kada im se kazuje, govore: "Mi vjerujemo u nj, on je Istina od Gospodara našeg, mi smo i prije bili muslimani. Oni će dobiti dvostruku nagradu za to što trpe i što lijepim zlo uzvraćaju i što od onoga što im dajemo udjeljuju." 7

Dakle, ovaj ajet govori o učenim, iskrenim i dobrim robovima, sljedbenicima Knjige (ehlul-kitabijama) koji su povjerovali u Kur'an kada je objavljen. O njima Allah, dž.š., na drugom mjestu u Kur'anu kaže:

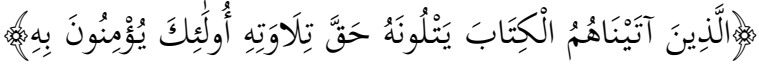

"Neki od sljedbenika Knjige čitaju je onako kako je objavljena, oni vjeruju u nju." 8 Evo i hadisa koji govori na tu temu:

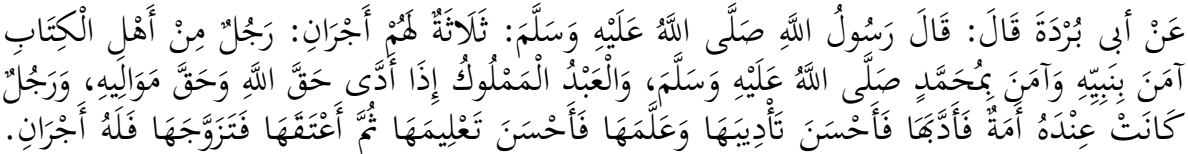

(الشيخان)

Ebu Burdete, r.a., prenosi da je Vjerovjesnik, s.a.V.s., rekao:

"Trojica će dobiti dvostruku nagradu: čovjek sljedbenik Knjige koji je vjerovao svome Vjerovjesniku a zatim povjerovao u Muhammeda, s.a.v.s., (doživio ga i slijedio ga) taj će imati dvostruku nagradu, rob koji je u nečijem vlasništvu pa izvršava obaveze prema Allahu i prema svome gospodaru, taj će imati dvostruku nagradu i čovjek koji ima robinju pa je odgaja i lijepo odgoji, lijepo je poduči a zatim je oslobodi i oženi se njome, i njemu pripadaju dvije nagrade."9

Prema tome ehlul-kitabije, sljedbenici ranijih nebeskih knjiga su $\mathrm{u}$ prednosti, kada povjeruju u Muhammeda, s.a.v.s., u odnosu na mušrike i njima slične. To potvrđuje naredni hadis:

\footnotetext{
${ }^{7}$ Kur'an, El-Kasas, 52-54.

${ }^{8}$ Kur'an, El-Bekare, 121.

${ }^{9}$ Bilježe ga Buhari i Muslim.
} 


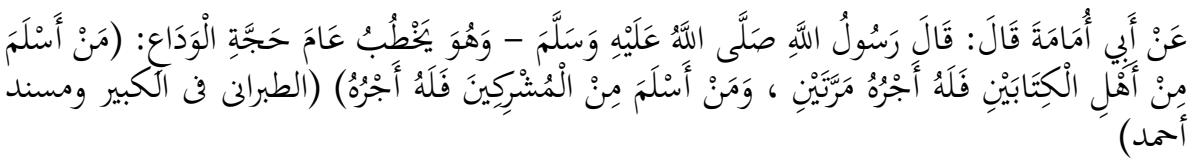

Ebu Umame, r.a., prenosi da je Allahov Poslanik, s.a.v.s., držeći hutbu na Oprosnom hadžu, između ostalog rekao i ovo: "Ko od sljedbenika ranije dvije nebeske knjiga/ehlul-kitabejni prihvati islam imat će dvostruku nagradu, a ko od mušrika pređe na islam imat će jednu nagradu." 10

\section{Sljedbenici Muhammeda, s.a.v.s., od njegovog ummeta}

Nakon što su se ehlul-kitabije hvalisale da će dobiti dvostruku nagradu, kako je već navedeno, Allah, dž.š., objavljuje ajet vezan za Poslanika, s.a.v.s., i njegov ummet:

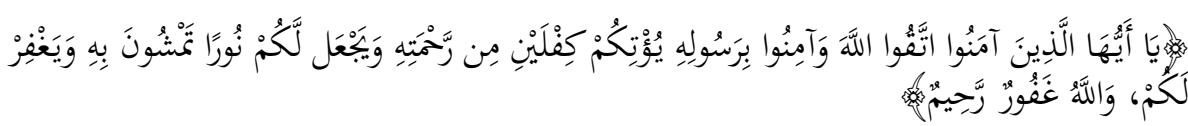

"O vi koji vjerujete - Allaha se bojte i u Poslanika Njegova vjerujte. On će vam dvostruku milost Svoju darovati, i dat će vam svjetlo pomoću kog ćete ići, i oprostit će vam, jer Allah prašta i milostiv je." ${ }^{11}$ Kao što vidimo, ovdje se pored dvostruke milosti od Allaha, dž.s.., obećava i svjetlo, tj. uputa pomoću koje će izići iz sljepila i neznanja, kao i oprost od Gospodara njihova. Kao odgovor na hvalisanje ehlul-kitabija Allah, dž.š., objavljuje ovaj ajet, sa kojim i završava ovu časnu suru:

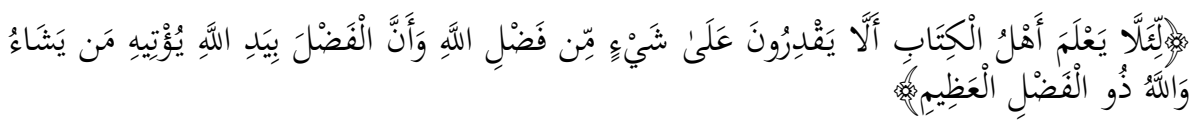

"I neka sljedbenici Knjige znaju da oni nikakvu Allahovu blagodat neće dobiti, jer je blagodat samo u Allahovoj ruci, daje je onome kojem On hoće; a u Allaha je blagodat najveća." ${ }^{12}$ Poznati komentator Kur'ana Ibn Džerir -rahimehullah- kaže: Neka budu sigurni i uvjereni da oni ne mogu spriječiti ono što Allah dadne, niti dati ono što On uskrati. ${ }^{13}$

\footnotetext{
${ }^{10}$ Bilježe ga Taberani u Kebiru i Ahmed u Musnedu, 21731.

${ }^{11}$ Kur'an, El-Hadid, 28.

${ }^{12}$ Kur'an, El-Hadid, 29.

${ }^{13}$ Tefsir Ibn-Kesir, sažetak, str. 1348.
} 


\section{Poslanikove supruge, tj. majke vjernika}

Poslanikove, s.a.v.s., supruge su majke vjernika i one imaju poseban status i deredžu. One imaju posebnu odgovornost za svoje ponašanje, tako da, ako bi se kod neke od njih pokazalo loše vladanje -što se nikada nije ni desilo jer je Allah, dž.š., zaštitio Poslanika i njegovu porodicu od toga- one bi imale dvostruki prijekor i kaznu. Isto tako Poslanikove, s.a.v.s., supruge, r.a., za svoju pokornost Allahu i Njegovom poslaniku, imaju dvostruku nagradu. O tome Allah, dž.š., u Kur'anu kaže:

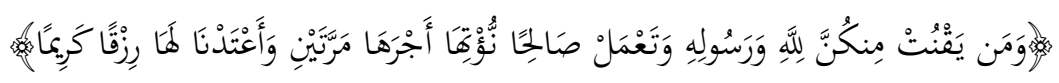

"...a onoj koja se bude Allahu i Poslaniku Njegovu pokoravala i dobra djela činila - dat ćemo nagradu dvostruku i pripremit ćemo joj opskrbu plemenitu."14 $\mathrm{Sa}$ ovom plemenitom opskrbom se misli na Džennet i njegova boravišta u društvu Poslanika, s.a.v.s., iznad ostalih stvorenja. ${ }^{15}$

Naredni hadis od Ebu Umame, r.a., u sebi sadrži već spomenute četiri vrste osoba koje će imati dvostruku nagradu:

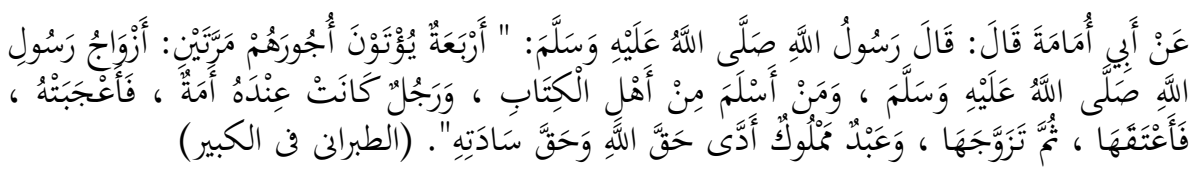

"Četverica će dobiti dvostruku nagradu: Pejgamberove, s.a.v.s., supruge, onaj ko pređe na islam od sljedbenika ranijih nebeskih knjiga, čovjek koji ima robinju koja mu se svidi pa je oslobodi i onda se njome oženi, rob koji izvršava obaveze prema Allahu i prema svojim vlasnicima." 16

\section{Oni koji budu vjerovali i dobra djela činili}

Prije toga da vidimo šta Allah, dž.š., kaže za one koji se baziraju samo na ovozemni život:

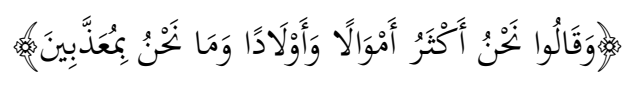

\footnotetext{
${ }^{14}$ Kur'an, El-Ahzab, 31.

${ }^{15}$ Kurtubijev tefsir, 14/172 i Tefsir Ibn-Kesir, sažetak, str. 1067.

${ }^{16}$ Bilježi ga Taberani u Kebiru, 7760.
} 
"Oni su govorili: Imamo više imetka i djece; mi nećemo biti mučeni!"17 Oni su se ponosili mnoštvom onoga što posjeduju i mnoštvom djece, vjerujući da je to dokaz Allahove ljubavi prema njima i Njegove brige za njih, navodno da im On ne bi dao tako nešto na dunjaluku, a zatim ih kaznio na ahiretu. Međutim, obilna opskrba na dunjaluku nije garancija sreće na ahiretu, pa neka ne misle da će ih mnoštvo djece i imetka spasiti i pomoći im. ${ }^{18}$

Allah, dž.š., u drugom ajetu kaže:

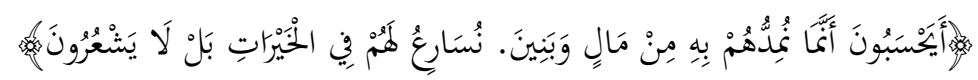

"Misle li oni - kad ih imetkom i sinovima pomažemo, da žurimo da im neko dobro učinimo? Nikako, ali oni ne opažaju."19

Allah, dž.š., dalje govori ukazujući da oni pogrešno razmišljaju:

$$
\text { 䒠 }
$$

"Ni imeci vaši ni djeca vaša neće vas učiniti Nama bliskim;"20 tj. da oni nisu dokaz Naše ljubavi prema vama, niti brige za vas.

U jednom hadisu koji prenosi Ebu Hurejre, r.a., Allahov Poslanik, s.a.v.s., kaže:

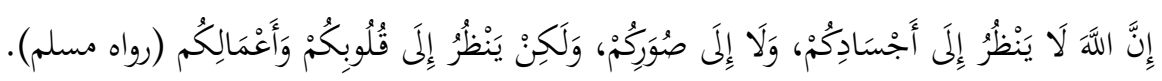

"Zaista Allah dž.š., ne gleda u vaša tijela niti u vaše likove, nego gleda u vaša srca i vaša djela." 21

Samo iskrena vjera i dobra djela vode Allahovom, dž.š., zadovoljstvu i nagradi:

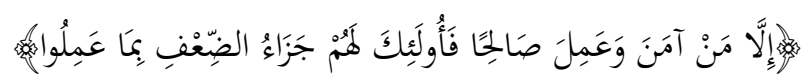

"Samo onima koji budu vjerovali i dobra djela činili čeka višestruka nagrada za ono što su radili," tj. Nama vas približuju vjerovanje i činjenje dobra. Seid ibn Džubejr je o značenju ovog ajeta

\footnotetext{
${ }^{17}$ Kur'an, Sebe', 35.

${ }^{18}$ Kurtubijev tefsir, 14/293.

${ }^{19}$ Kur'an, El-Mu'minun, 55-56.

${ }^{20}$ Kur'an, Sebe', 37.

${ }^{21}$ Bilježi ga Muslim.
} 
rekao: "Onome koji vjeruje i čini dobra djela, imetak i djeca neće naškoditi na dunjaluku. Kada dobar čovjek ima hajirli djecu i halal imetak onda je to prava blagodat za vjernika. Pojedini učenjaci kažu da je ovaj ajet dokaz davanja prednosti bogatstvu nad siromaštvom. Muhammed ibn Keab El-Kurezi je rekao: "Kada vjernik bude bogat i bogobojazan, Allah, dž.š., će mu dati dvostruku nagradu zbog ovog ajeta." $^{22}$

Ovaj ajet se ovako završava:

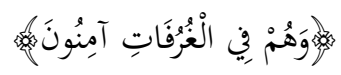

"i oni će u visokim odajama biti sigurni." ${ }^{23} \mathrm{Tj}$. Njihovo dobro djelo će se umnožiti od deset do sedam stotina puta i u visokim prebivalištima $u$ Džennetu bit će sigurni od svakog straha, neugodnosti i uznemiravanja.

\section{Onaj koji traži znanje}

Traženjem korisne nauke u ime Allah, dž.š., postiže se također dupla nagrada, kao što to stoji na narednim hadisima:

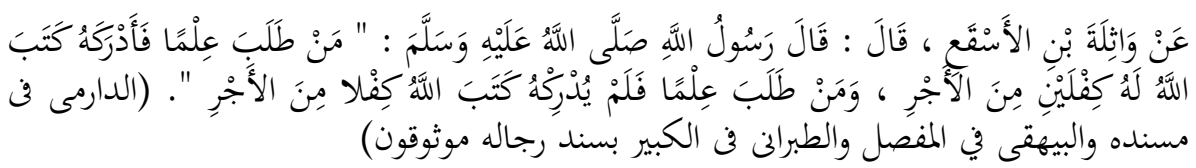

Vasile ibn El-Eska', r.a., prenosi da je Allahov Poslanik, s.a.v.s., rekao: "Ko bude tražio nauku pa u tome uspije Allah će mu upisati dvostruku nagradu, a ko bude tražio nauku pa u tome ne uspije Allah će mu upisati jednu nagradu." 24

Ovaj hadis je zabilježio i Ebu Je'ala dodavši na kraju pojašnjenje:

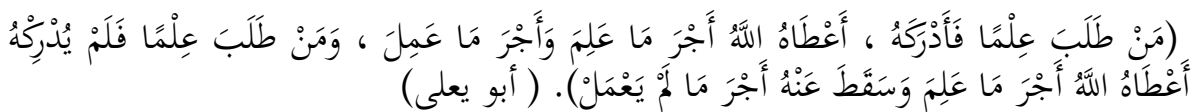

"Ko bude tražio nauku pa to postigne Allah će mu dati nagradu za znanje i nagradu za trud, a ko bude tražio nauku pa to ne postigne Allah

\footnotetext{
${ }^{22}$ Kurtubijev tefsir, 14/294.

${ }^{23}$ Kur'an, Sebe', 37.

24 Bilježe ga Darimi, Bejheki u El-Mufessalu i Taberani u Kebiru, 17660 sa pouzdanim lancem prenosioca.
} 
će mu dati nagradu za ono što je već znao, a neće biti kažnjen za ono što nije radio (jer to nije znao)." 25

\section{Dobar rob koji je poslušan svome vlasniku}

U ranije prethodnim hadisima već je spomenuta ova vrsta ljudi. Evo još nekih hadisa na ovu temu:

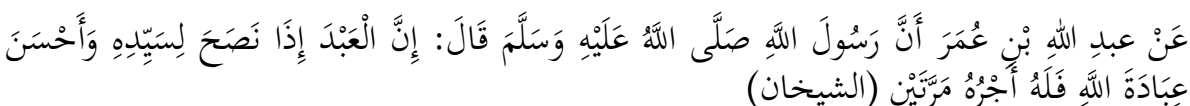

Abdullah ibn Omer, r.a., prenosi da je Vjerovjesnik, s.a.v.s., rekao: "Kada rob bude poslušan svome vlasniku i bude lijepo izvršavao svoj ibadet/obožavanje Allaha, njemu pripada dupla nagrada." 26

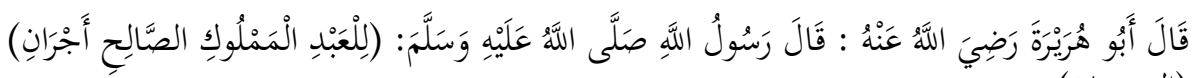
(الشيخان)

Ebu Hurejre, r.a., prenosi da je Allahov Poslanik, s.a.v.s., rekao: "Dobrom robu koji je u nečijem vlasništvu pripada dupla nagrada."27

\section{Učač Kur'ana}

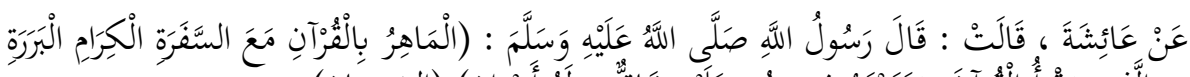

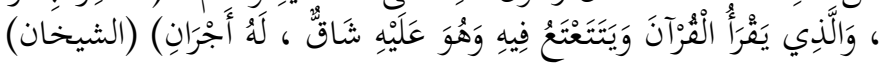

Aiša, r.a., prenosi da je Allahov Poslanik, s.a.v.s., rekao: "Onaj koji vješto uči Kur'an će biti sa odabranim časnim melekima a onaj koji uči Kur'an, zamuckujući i pri tome osjeća poteškoću, taj će imati dvostruku nagradu." ${ }^{28} \mathrm{U}$ drugom hadisu se kaže:

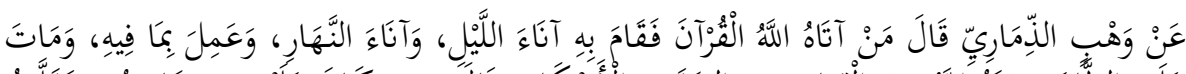

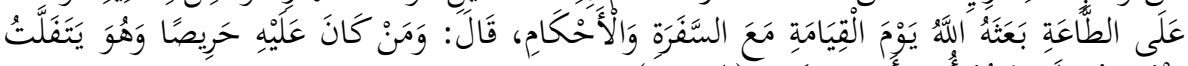

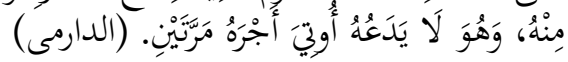

Vehb Ez-Zimari je rekao: "Kome Allah dadne Kur'an i on bude noći i dane provodio učeći ga, primjenjujući ono što je u njemu i umre u

\footnotetext{
${ }^{25}$ Bilježi ga Ebu Je'ala.

${ }^{26}$ Bilježe ga Buhari i Muslim.

${ }^{27}$ Bilježe ga Buhari i Muslim.

${ }^{28}$ Bilježe ga Buhari i Muslim.
} 
pokornosti Allahu, dž.š., Allah će ga proživjeti u skupini odabranih meleka i poslanika, a ko bude nastojao učiti Kur'an i uz to što ga ne može zapamtiti, on ga ipak nije zapostavio, dobiće dvostruku nagradu." 29

\section{Učenje Kur'ana gledajući u Mushaf}

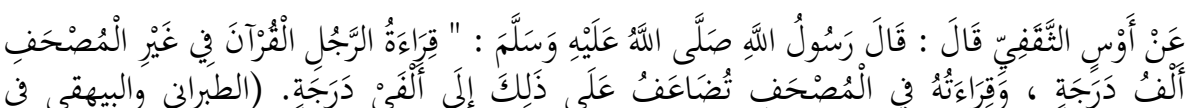

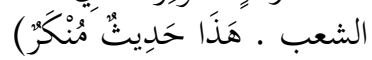

Evs Es-Sekafi kaže da je Allahov Poslanik, s.a.v.s., rekao: "Za učenje čovjeka u Kur'ana bez gledanja u mushaf dobija se hiljadu deredža a za učenje Kur'ana gledajući u mushaf udvostučava se ta nagrada do dvije hiljade deredža." 30

Za učenje Kur'ana sa razumijevanjem ima se, također, dvostruka nagrada:

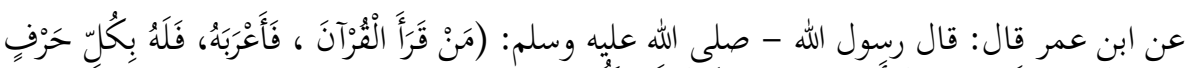

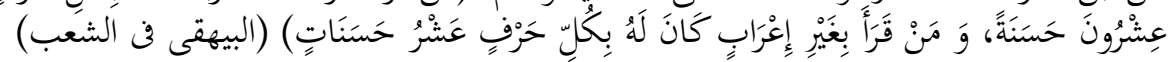

Ibn Omer, r.a., prenosi da je Allahov Poslanik, s.a.v.s., rekao: "Ko bude učio Kur'an sa razumijevanjem imat će za svaki proučeni harf dvadeset sevapa, a ko bude učio Kur'an bez razumijevanja imat će za svaki proučeni harf deset sevapa." 31

Već smo spomenuli da se dobra djela nagrađuju nekada desetorostruko, na što ukazuje slijedeća predaja:

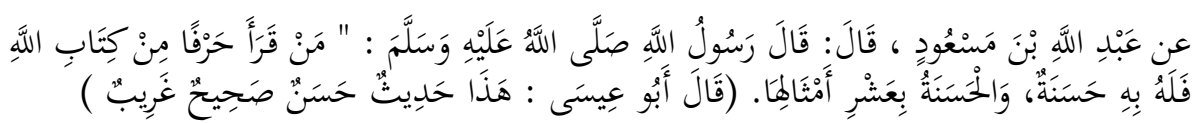

Abdullah ibn Mes'ud, r.a., prenosi da je Poslanik, s.a.v.s., rekao: "Ko prouči jedan harf iz Allahove knjige (Kur'ana) imat će dobro djelo, a dobro se nagrađuje deseterostruko." 32

\footnotetext{
${ }^{29}$ Bilježi ga Darimi.

${ }^{30}$ Bilježe ga Taberani i Bejheku u Šuabu, slab hadis.

${ }^{31}$ Bilježi ga Bejheku u Šuabu.

${ }^{32}$ Bilježi ga Tirmizi, sahih.
} 


\section{Slušanje učenja Kur'ana}

Vidjeli smo da onaj koji uči Kur'an ima veliku nagradu, ali se velika nagrada obećava i onome ko sluša učenja Kur'ana. Moguće je taj sevap zaraditi, pogotovo uz ramazan, kada smo u prilici slušati mukabele koje se uče u našim džamijama. Za ovakvo mišljenje poslužit će nam izreka ovog tabi'ina:

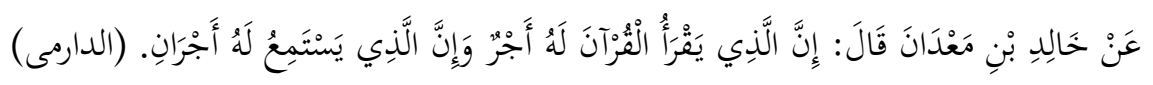

Halid ibn Mea'dan (El-Kila'i) je rekao: "Zaista onaj koji uči Kur'an ima nagradu a onaj koji ga sluša ima dvostruku nagradu." ${ }^{\text {33 }}$

\section{Pravedan sudija ili vladar}

Ako sudija uloži sve od sebe da pravedno presudi imat će dvostruku nagradu, kao što je to obećao Pejgamber, s.a.v.s., u svojim hadisima:

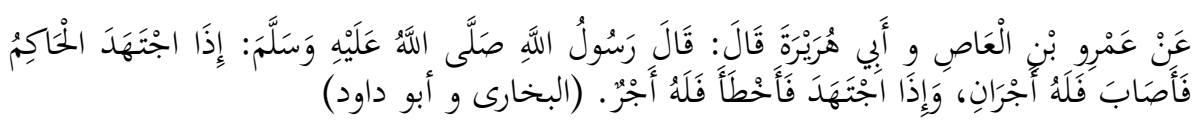

Ebu Hurejre i Amr ibn El-A's, r.a., prenose da je Allahov Poslanik, s.a.v.s., rekao: "Kada se sudija potrudi i uspije pravedno presuditi imat će dvostruku nagradu, a kada se potrudi pa pogriješi u presudi imat će jednu nagradu." ${ }^{34}$

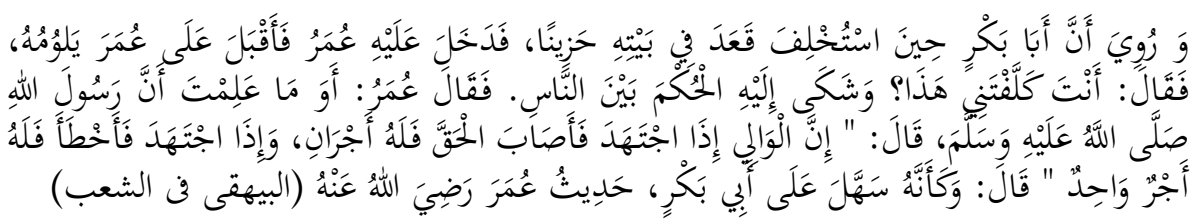

Prenosi se da je Ebu Bekr, r.a., kada je preuzeo hilafet sjedio u svojoj kući ožalošćen. Kod njega je ušao Omer, r.a., pa mu se Ebu Bekr, r.a., obrati kritikujući ga i reče: -Ti si me opteretio sa ovim obavezama. Bojao se obaveze presuđivanja među ljudima. Tada mu Omer, r.a., reče: -Pa zar ne znaš da je Allahov Poslanik, s.a.v.s., rekao: "Kada se vladar potrudi i uspije pravedno presuditi imat će dvostruku nagradu, a ako pogriješi imat će jednu nagradu." Pa je Omerov, r.a., govor olakšao Ebu

\footnotetext{
${ }^{33}$ Bilježi ga Darimi, 3366.

${ }^{34}$ Bilježe ga Buhari i Ebu-Davud.
} 
Bekr, r.a. ${ }^{35} \mathrm{U}$ narednom hadisu govori se o odgovornosti vladara i njegovoj udvostručenoj nagradi, ako bude pokoran svome Stvoritelju:

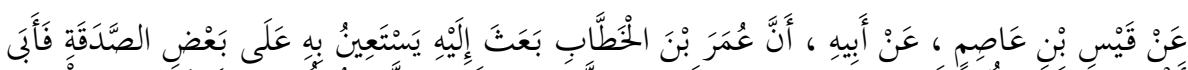

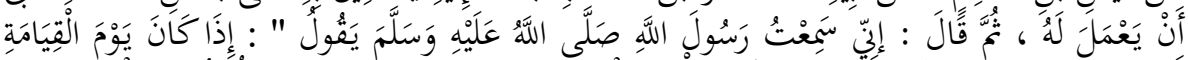

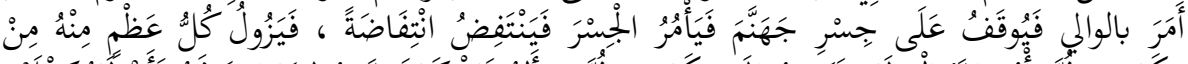

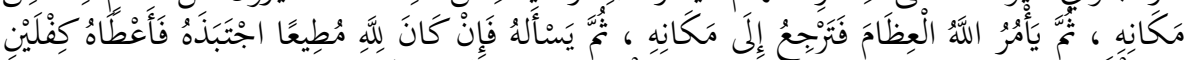

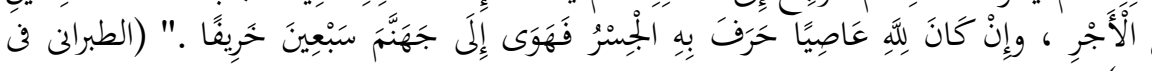

Kajs ibn Asim prenosi od svoga oca da je Omer, r.a., od njega tražio da mu pomogne oko sakupljanja zekata, pa je ovaj to nije prihvatio a zatim rekao: Ja sam zaista čuo Allahovog Poslanika, s.a.v.s., da kaže: "Kada bude Sudnji dan, vladar će biti doveden na most iznad Džehennema (Sirat-ćupriju), pa će Uzvišeni Allah narediti da se most zatrese, tako da će mu se svaka kost pomaknuti sa svog mjesta. Zatim će Allah, dž.š., narediti da se svaka kost vrati na svoje mjesto, pa će biti ispitivan, pa ako je bio Allahu pokoran, biće spašen i dobiće udvostručenu nagradu, a ako bude prema Allahu griješan, propast će kroz most u Džehennem dubine (udaljenosti) sedamdeset godina."36

\section{Kompletno uzimanje abdesta}

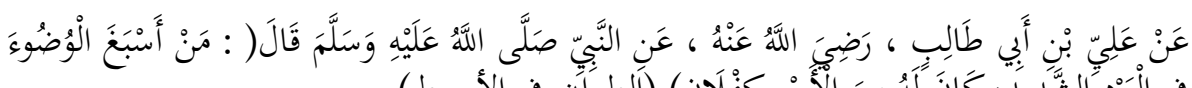

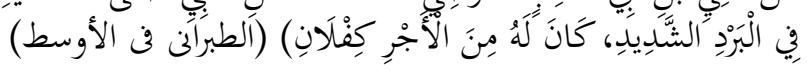

Alija, r.a., prenosi da je Allahov Poslanik, s.a.v.s., rekao: "Ko potpuno uzme abdest na velikoj hladnoći imat će dvostruku nagradu."37

\section{Uzimanje abdesta perući dijelove po dva puta}

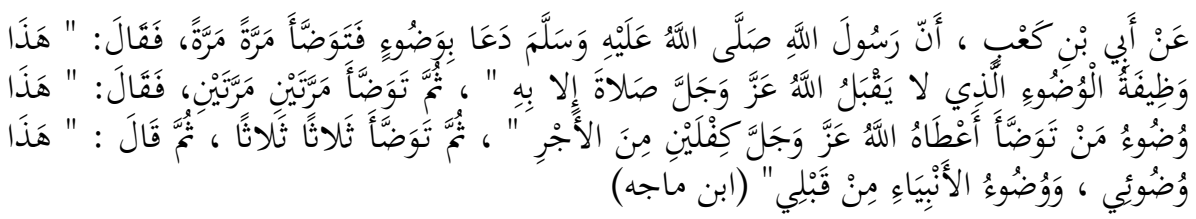

\footnotetext{
${ }^{35}$ Bilježi ga Bejheki u Šuabu.

${ }^{36}$ Bilježi ga Taberani u Kebiru.

${ }^{37}$ Bilježi ga Taberani u Evsatu.
} 
Ubejj ibn Keab, r.a., kaže: Allahov Poslanik, s.a.v.s., je zatražio vodu pa je uzeo abdest perući dijelove jedanput, te je rekao: "Ovo je minimum kod abdesta, bez kojeg Allah ne prima namaz." Zatim je uzeo abdest perući dijelove po dva puta, te je rekao: "Ko ovako bude uzimao abdest, Allah će mu dati dvostruku nagradu." Nakon toga je uzeo abdest perući organe po tri puta, te reče: "Ovo je moj (kompletni) abdest i abdest poslanika prije mene." 38

\section{Pranje ruku prije i nakon jela}

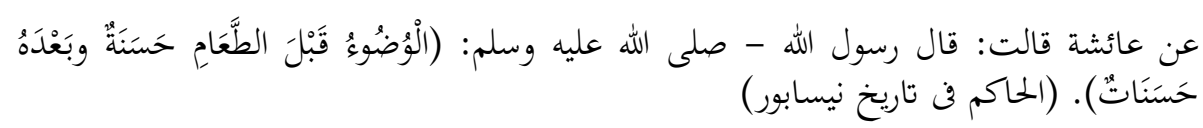

Aiša, r.a., prenosi da je Allahov Poslanik, s.a.v.s., rekao: "Pranje ruku prije jela je dobro djelo a nakon jela je više dobrih dijela (sevapa)."39

U Aišinom, r.a., hadisu prvi dio (tj. pranje ruku prije jela) se odnosi na vjerozakon poslanika koji su bili prije Muhammeda, s.a.v.s., a drugi dio je vjerozakon Muhammeda, s.a.v.s., za ovaj ummet, pa je zbog toga u njemu spomenuto da za pranje ruku nakon jela imamo više sevapa. $\mathrm{Na}$ to ukazuje i Selmanova, r.a., predaja u kojoj on kaže:

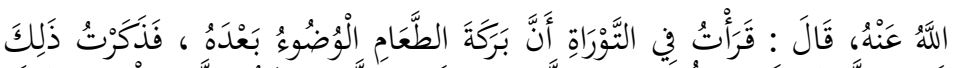

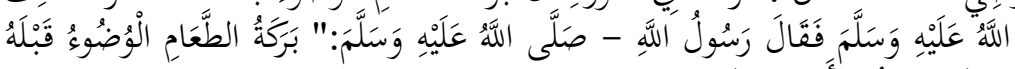

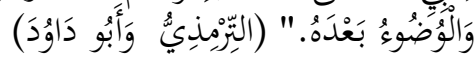

"Pročitao sam u Tevratu da je blagoslov/berićet hrane u pranju ruku nakon jela To sam spomenuo Poslaniku, s.a.v.s., pa on reče: "Berićet/blagoslov hrane u pranju ruku prije i nakon jela." 40 Slična situacija je i u nagradi za postenje Dana Ašure, koja je vezana za Musa'a, a.s., gdje se za nagradu obećava brisanje manjih grijeha u toku

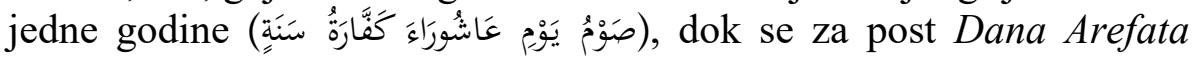

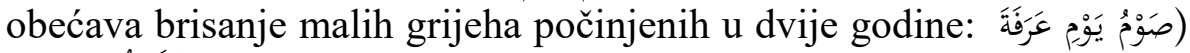
(كَفَّارَة سَنَتَيْنِ. U tome se vidi davanje prednosti Muhammedu, s.a.v.s., i njegovom vjerozakonu u odnosu na ranije vjerozakone, time što imaju dvostruku nagradu.

\footnotetext{
${ }^{38}$ Bilježi ga Ibn Madže, 1/146 (420).

${ }^{39}$ Bilježi ga Hakim u Tarihu Nejsabur.

${ }^{40}$ Bilježe ga Tirmizi i Ebu Davud.
} 


\section{Vrijednost ikindije-namaza}

Allah, dž.š., u Kur'anu govori o obaveznosti čuvanja pet dnevnih namaza a posebno naglašava ikindiju-namaz:

$$
\text { pron }
$$

"Redovno molitvu obavljajte, naročito srednji namaz i pred Allahom ponizno stojte." 41

Također Poslanik, s.a.v.s., govori o vrijednosti ikindije-namaza pa kaže:

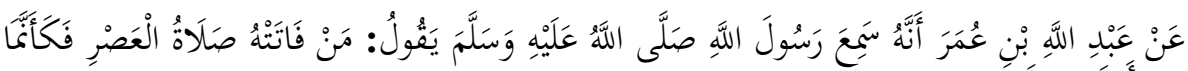

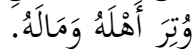

Abdullah ibn Omer, r.a., je čuo Allahovog Poslanika, s.a.v.s., da kaže: "Onaj koga prođe ikindija-namaz kao da je izgubio i porodicu i imetak." 42

Prema tome nije ni čudo što se onima koji budu obavljali ovaj namaz obećava dupla nagrada:

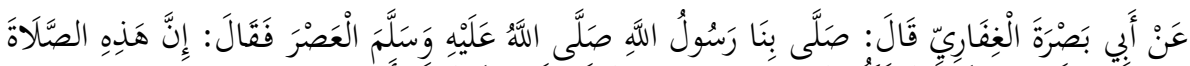

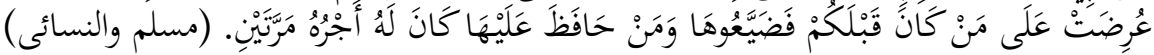

Ebu Basre El-Gifari, r.a., kaže: Allahov Poslanik, s.a.v.s., je klanjao s nama ikindiju-namaz pa je rekao: "Ovo je namaz koji je ponuđen onima koji su bili prije vas pa su ga zanemarili. Zaista, onaj ko ga bude obavljao imat će dvostruku nagradu." ${ }^{43}$

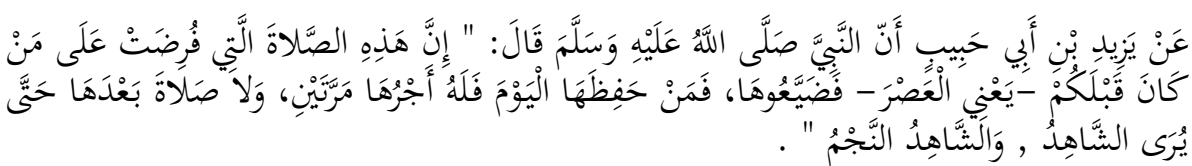

Jezid ibn Ebi Habib kaže da je Vjerovjesnik, s.a.v.s., rekao: "Zaista je ovaj namaz -tj. ikindija- bio propisan onima koji su bili prije vas pa su ga zanemarili. Ko ga danas imat će za njega dvostruku nagradu, i nema namaza nakon njega sve dok se ne ugleda šahid, a šahid je zvijezda." 44

\footnotetext{
${ }^{41}$ Kur'an, El-Bekare, 238.

${ }^{42}$ Bilježi ga Buhari.

43 Bilježe ga Muslim i Nesai.

${ }^{44}$ Bilježi ga Abdurrezzak u Musannefu, hadis je mursel.
} 


\section{Umnožavanje dobrih dijela petkom}

Od vrijednosti i vrlina Allahu, dž.š., najdražeg dana, petka je i da se u njemu umnožavaju nagrade za dobra djela.

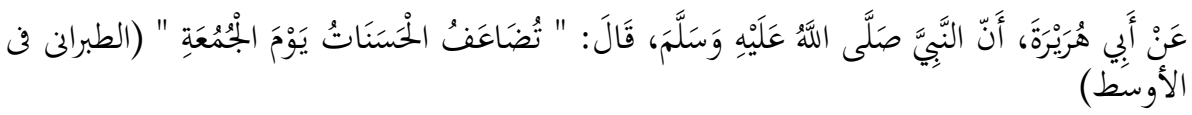

Ebu Hurejre, r.a., prenosi da je Allahov Poslanik, s.a.v.s., rekao: "Dobra djela se višestruko vrednuju petkom." 45

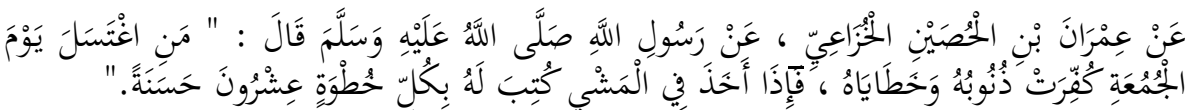

Imran ibn Husajn, r.a., prenosi da je Allahov Poslanik, s.a.v.s., rekao: "Ko se okupa petkom očisti se od grijeha i prestupa a kada krene $\mathrm{u}$ džamiju, svakim korakom mu se piše dvadeset sevapa."

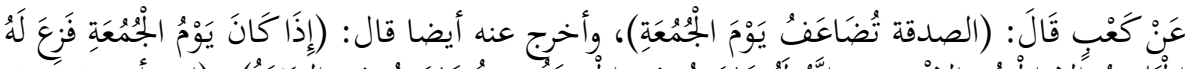

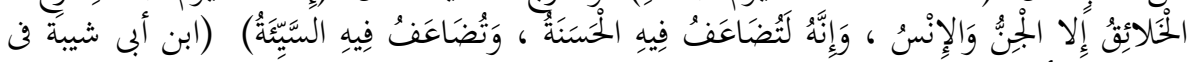

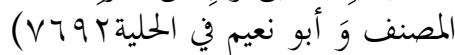

Keab, r.a., kaže: "Sadaka koja se udijeli petkom se umnožava," i također je rekao: "Kada nastupi petak uplaše se sva stvorenja osim džina i ljudi, i u njemu se umnožavaju i dobra i loša djela." 47

\section{Kupanje petkom i prisustvo džumi-namazu}

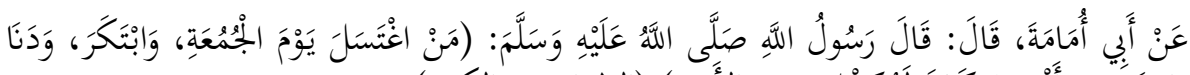

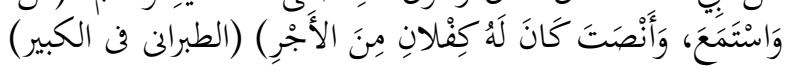

Ebu Umame, r.a., kaže da je Allahov Poslanik, s.a.v.s., rekao: "Ko se okupa petkom, podrani u džamiju, primakne se i odsluša ćuteći hutbu, imat će dvostruku nagradu." 48

\footnotetext{
45 Bilježi ga Taberani u Evsatu.

${ }^{46}$ Bilježi ga Taberani.

${ }^{47}$ Bilježe ga Ibn Ebi Šejbe u Musannefu i Ebu Nuajm u El-Hil-ji, 7692.

${ }^{48}$ Bilježi ga Taberani u Kebiru.
} 


\section{Kupanje petkom nakon bračnog odnosa sa suprugom}

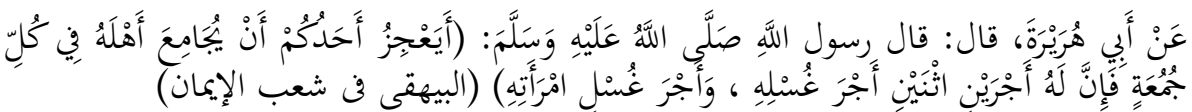

Ebu Hurejre, r.a., prenosi da je Allahov Poslanik, s.a.v.s., rekao: "Zar niste u stanju da imate bračni odnos sa svojom suprugom svake sedmice?! Ko to uradi ime dvije nagrade, nagradu zbog svog kupanja i nagradu zbog kupanja svoje supruge." 49

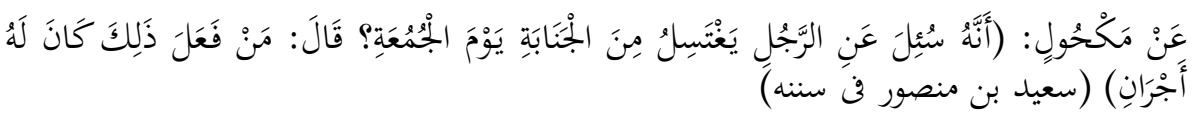

Mekhul je upitan o kupanju petkom nakon bračnog odnosa sa svojom suprugom, pa je rekao: "Ko to uradi imat će dvostruku nagradu."50

\section{Pomno slušanje hutbe petkom}

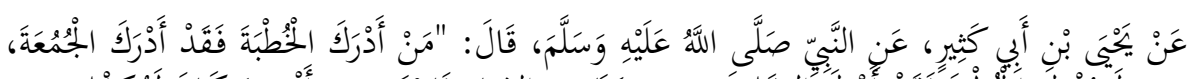

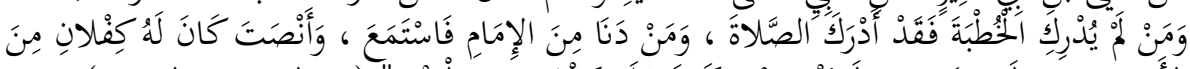

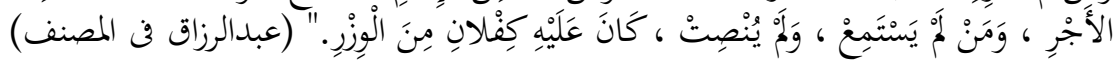

Jahja ibn Kesir kaže da je Vjerovjesnik, s.a.v.s., rekao: "Ko stigne na hutbu taj je stigao na džumu-namaz, a ko ne stigne na hutbu taj je stigao na namaz. Ko se primakne imamu i odsluša ćuteći hutbu, imat će dvije nagrade, a ko ne bude šutio i slušao taj će imati dva grijeha." ${ }^{51}$

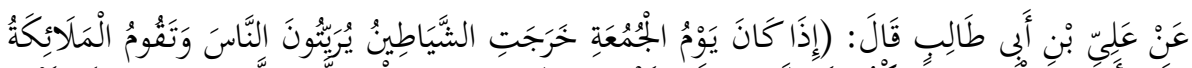

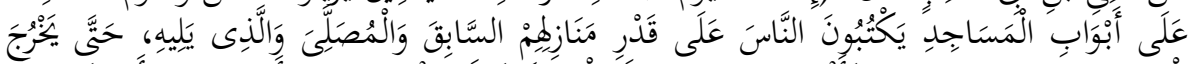

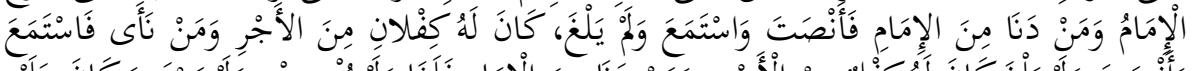

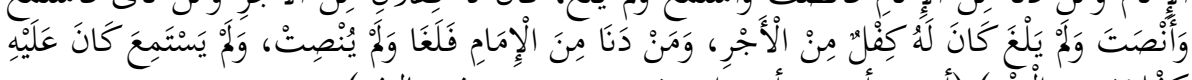

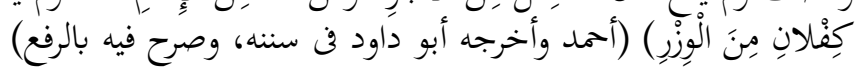

Alija ibn Ebi Talib, r.a., je rekao: "Kada nastupi dan petak izađu šejtani pa ljude odvraćaju a meleki budu na džamijskim vratima i popisuju ljude po njihovom pristizanju, od prvog klanjača, pa dalje koji slijede, sve dok se imam ne popne na minberu. Ko se primakne imamu pa pomno bude slušao i da se ničim drugim ne okupira, imat će dvostruku

\footnotetext{
${ }^{49}$ Bilježi ga Bejheki u Šuabu.

${ }^{50}$ Bilježi ga Seid ibn Mensur u Sunenu.

${ }^{51}$ Bilježi ga Abdurrezzak u Musannefu.
} 
nagradu. Ko se odmakne ali bude pomno slušao imat će jednu nagradu. Ko se primakne imamu ali se bude nečim zabavljao, te ne bude ćutao, niti slušao imat će dupli grijeh." ${ }^{52}$

\section{Klanjanje na lijevoj strani džamije}

Ako bi svi klanjači otišli na desnu stranu džamije, želeći postići vrijednost desne strane, onda bi onaj ko bi klanjao na lijevoj strani, Želeći time da očuva i aktivira lijevu stranu, imao dvostruku nagradu. Pogledajmo hadise na ovu temu:

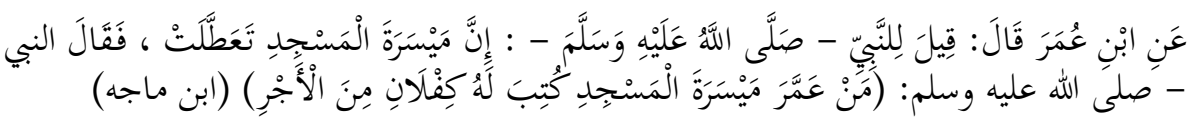

Ibn Omer, r.a., kaže da je Allahovom Poslaniku, s.a.v.s., rečeno: -Lijeva strana džamije je ostala pusta, pa je Poslanik, s.a.v.s., rekao: "Ko oživi lijevu stranu džamije, Allah će mu upisati dvostruku nagradu." 53

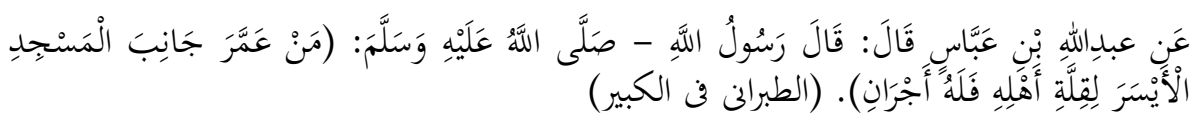

Abdullah ibn Abbas, r.a., prenosi da je Allahov Poslanik, s.a.v.s., rekao: "Ko oživi lijevu stranu džamije, zbog manjka klanjača na njoj, imat će dvostruku nagradu." 54

\section{Neklanjanje u prvom saffu/redu}

Opće poznato je da prvi saff ima svoju posebnu vrijednost, ali da bi se do njega stiglo, treba podraniti u džamiju i zauzeti svoje mjesto $u$ njemu. Međutim, kada neko dođe kasno onda ne bi trebao, želeći da uđe u prvi saff, uznemiravati druge klanjače, pogotovo one koji su došli prije njega, jer su oni preči za prvi saff od njega. Evo šta nam hadis po ovom pitanju kaže:

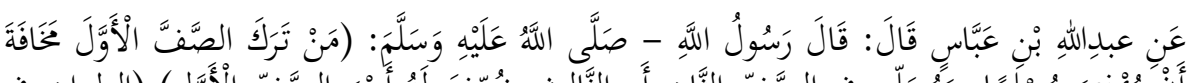

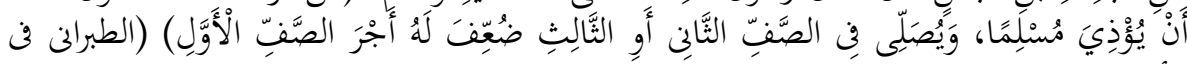

\footnotetext{
${ }^{52}$ Bilježi ga Ahmed, a Ebu Davud ga bilježi kao Poslanikove, s.a.v.s., riječi.

${ }^{53}$ Bilježi ga Ibn Madže.

${ }^{54}$ Bilježi ga Taberani u Kebiru.
} 
Abdullah ibn Abbas, r.a., prenosi da je Allahov Poslanik, s.a.v.s., rekao: "Ko izostavi klanjanje u prvo saffu bojeći se da će uznemiriti nekog od muslimana, pa klanja u drugom, ili u trećem saffu, njemu će biti udvostručena nagrada koja se dobija za klanjanje u prvom saffu." 55

\section{Predvođenje džemata/imamet i muezinjenje}

Jedan od malih predznaka Sudnjeg dana je da će se ljudi nećkati (odbijati) da budu imami, tj. da predvode zajedničko klanjanje u džamiji. Svakako da će oni koji budu imami a i oni koji budu mujezinili imati dvostruku nagradu, kao što se to pojašnjava ovim hadisom:

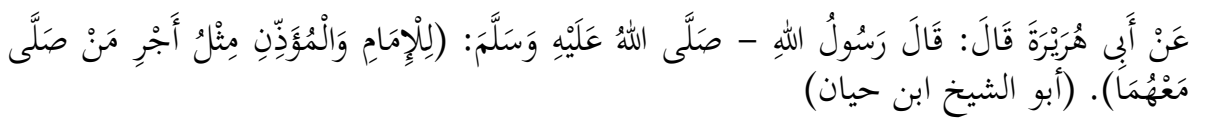

Ebu Hurejre, r.a., prenosi da je Allahov Poslanik, s.a.v.s., rekao: "Imamu i mujezinu pripada poput nagrade onih koji budu s njima klanjali." ${ }^{56}$ Svakako da nagrada neće biti nimalo umanjena klanjaču, kao što to potvrđuju drugi hadisi.

\section{Ponovno klanjanje namaza koji je obavljen sa tejemmumom}

Od uslova ispravnosti namaza je abdest, međutim kad se čovjek nađe u situaciji da nema vode, uzet će tejemmum/simbolično potiranje prašinom. Ako takav čovjek prije isteka namaskog vremena dođe do vode, pa obnovi namaz imat će dvostruku nagradu. Evo hadisa koji to potvrđuje:

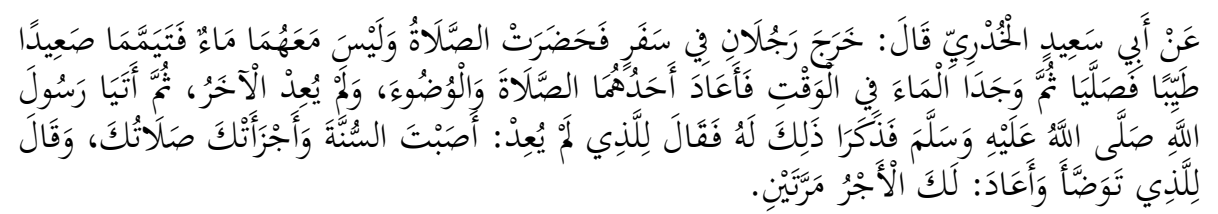

Ebu Seid El-Hudri, r.a., kaže da su dvojica ljudi krenuli na put, pa kada je nastupio namaz, nisu imali vode, te su klanjali nakon što su uzeli tejemmum. Kada su kasnije, dok je još trajalo namasko vrijeme, našli vodu, jedan od njih je uzeo abdest i ponovo klanjao, a drugi nije. Kada su došli Poslaniku, s.a.v.s., i ispričali mu to, on je onome koji nije

\footnotetext{
${ }^{55}$ Bilježi ga Taberani u Evsatu, hadis je daif.

${ }^{56}$ Bilježi ga Ebuš-Šejh Ibn Hajjan.
} 
ponovio namaz rekao: "Potrefio si sunnet i tvoj namaz ti je dovoljan." Onome koji je ponovo sa abdestom klanjao je rekao: "Ti imaš dvostruku nagradu."

\section{Dženaza-namaz}

Veliki sevap je ispratiti brata muslimana klanjajući mu dženazu-namaz. U nekim situacijama će onaj koji prisustvuje dženazi-namazu imati dvostruku nagradu. Evo hadisa koji ukazuju na te situacije:

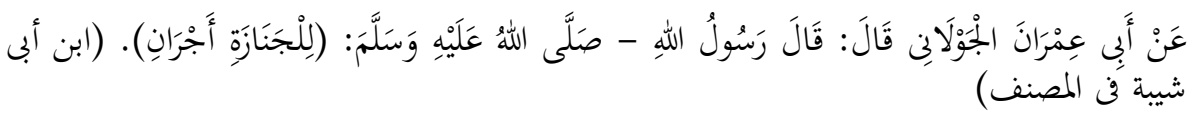

Ebu Imran El-Dževlani prenosi da je Allahov Poslanik, s.a.v.s., rekao: "Za dženazu-namaz se ima dupla nagrada." 58

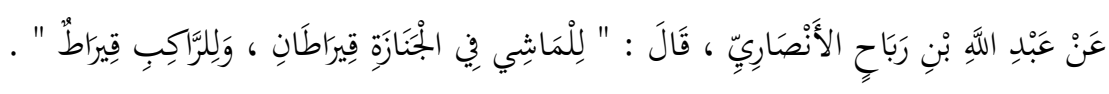

Jedan od tabi'ina (generacija nakon ashaba), Abdullah ibn Rebbah ElEnsari je rekao: "Onaj koji dženazu prati pješice imat će dva kirata (nagrade) a onaj koji jaše (ili se vozi) imat će jedan kirat."

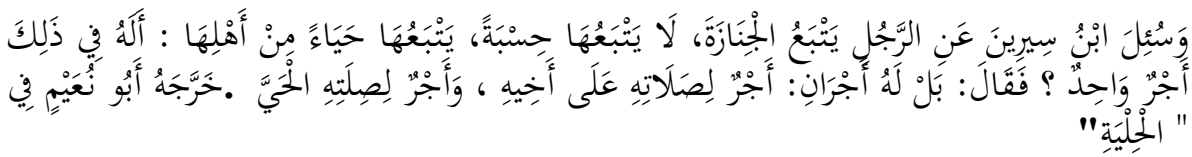

Poznat tabi'in Muhammed ibn Sirin je upitan: - Čovjek koji prati dženazu, ne nadajući se nagradi za to nego je prati iz stida prema njegovoj porodici, ima li za to jednu nagradu? On reče: -On ima dvije nagrade; nagradu zbog klanjanja dženaze svome bratu i nagradu zbog održavanja kontakta sa živima." 59

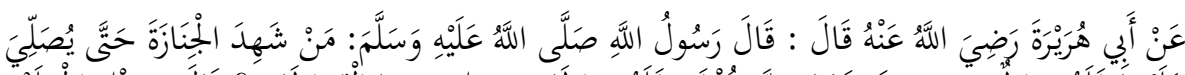

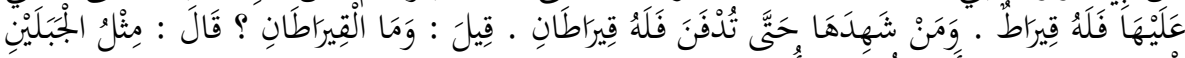

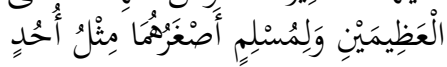

Ebu Hurejre, r.a., prenosi da je Allahov Poslanik, s.a.v.s., rekao: "Ko prisustvuje dženazi namazu dok se ne klanja imat će nagradu jednog kirata, a ko prisustvuje sve dok se ne ukopa imat će dva kirata. Neko

\footnotetext{
${ }^{57}$ Bilježi ga Ebu Davud.

${ }^{58}$ Bilježi ga Ibn Ebi Šejbe u svom Musannefu.

${ }^{59}$ Bilježi ga Ebu Nuajm u El-Hil-ji.
} 
upita: -A šta su dva kirata? On reče: -Poput dva velika brda." Kod Muslima stoji: "Manji od ta dva brda je poput brda Uhud."

\section{Sadaka ili zekat udijeljen rodbini}

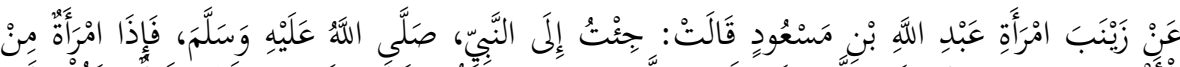

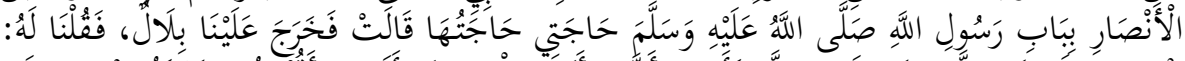

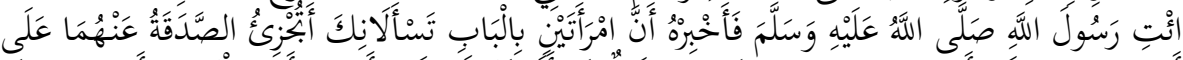

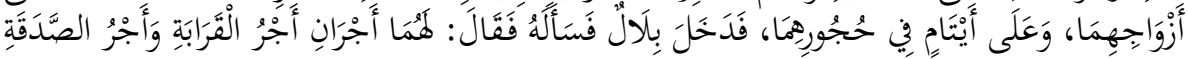
(الشيخِان)

Zejneba, supruga Abdullaha ibn Mes'uda, r.a., priča: Došla sam do Vjerovjesnika, s.a.v.s., pa sam zatekla neku ženu ensarijku, koja je također došla zbog nake potrebe. Naišao je Bilal, r.a., pa smo mu rekle: -Uđi kod Pejgambera, s.a.v.s., i reci mu da su pred vratima dvije žene koje pitaju, je li im ispravno da zekat daju svojim muževima i jetimima za koje se njih dvije brinu? Bilal je ušao i upitao, pa kada je izašao reče: "One imaju dvostruku nagradu; nagrada za održavanje rodbinskih veza i nagrada za zekat." 60

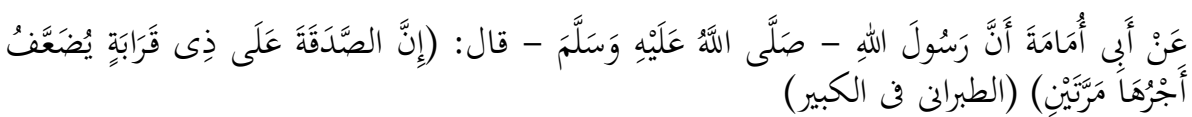

Ebu Umame, r.a., prenosi da je Allahov Poslanik, s.a.v.s., rekao: "Zekat koji se udijeli rodbini ima dvostruku nagradu." ${ }^{61}$

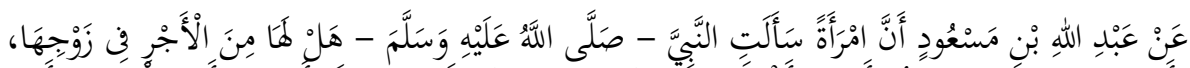

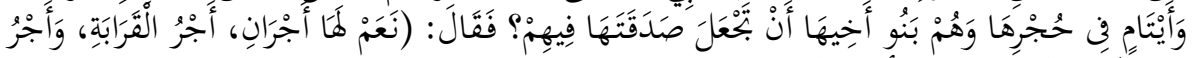

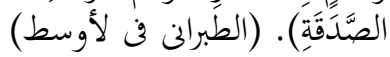

Abdullah ibn Mes'ud, r.a., kaže da je neka žena pitala Vjerovjesnika, s.a.v.s., da li ima nagradu i je li joj ispravno ako udijeli zekat svome mužu i jetimima za koje se ona brine a to su njeni bratići? Poslanik, s.a.v.s., je odgovorio: -Ona ima dvostruku nagradu, nagradu za održavanje rodbinskih veza i nagradu za obavezu zekata." ${ }^{62}$

\footnotetext{
${ }^{60}$ Buhari i Muslim.

61 Taberani u Kebiru.

${ }^{62}$ Bilježi ga Taberani u Evsatu.
} 


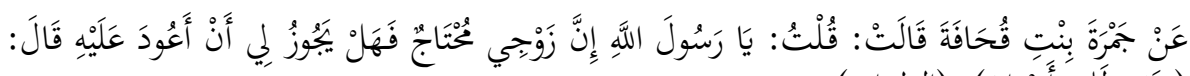

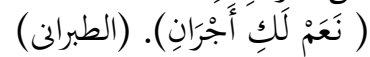

Džemre bit Kuhafe je upitala Allahovog Poslanika, s.a.v.s.: "Moj muž je potreban, pa je li dozvoljeno da mu udijelim sadaku? On reče: -Jeste, i imaš dvostruku nagradu." 63

\section{Vrijednost pogibije na Allahovom putu/šehadet u borbi protiv ehlul-kitabija}

Šehadet/Pogibija na Allahovom putu ima poseban sevab i nagradu ali kada musliman u džihadu pogine od strane pripadnika ranijih nebeskih knjiga/ehlul-kitab onda mu se nagrada udvostručava:

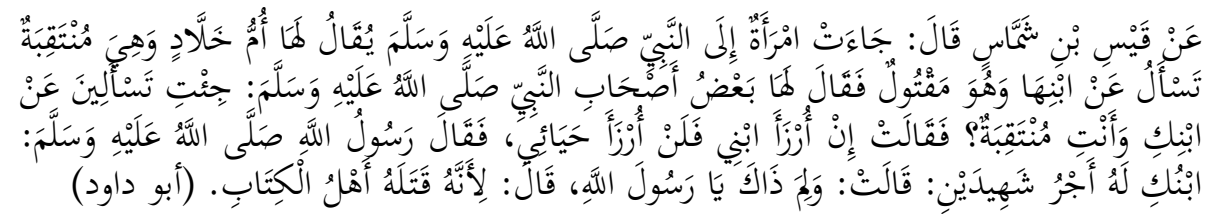

Kajs ibn Šemmas, (tabi'in) je rekao: "Neka žena -zvana Ummu Halladje došla kod Vjerovjesnika, s.a.v.s., nepokrivenog lica, pitati za njenog sina koji je poginuo. Neko od prisutnih ashaba joj reče: -Došla si pitati o sinu a lice ti nije prekriveno. Ona reče: -Ako sam izgubila sina nisam ostala bez stida. Poslanik, s.a.v.s., joj reče: -Tvoj sin ima nagradu dvojice šehida. Ona upita: -A zbog čega to? On reče: Zato što ga je ubio pripadnik ehlul-kitabija (židov ili kršćanin)."64

\section{Pogibija na moru}

Pored gore spomenutog i šehid u morskoj bici ima dvostruku nagradu:

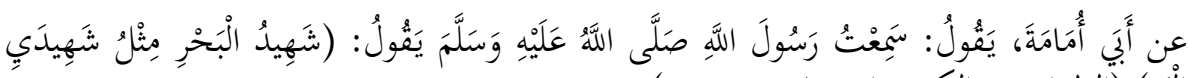

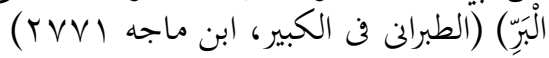

Ebu Umame, r.a., kaže da je čuo Allahovog Poslanika, s.a.v.s., da kaže: "Šehid na moru ima nagradu kao dvojica šehida na kopnu." 65

\footnotetext{
${ }^{63}$ Bilježi ga Taberani.

${ }^{64}$ Bilježi ga Ebu Davud.

${ }^{65}$ Bilježe ga Taberani u Kebiru i Ibn Madže, 2771.
} 


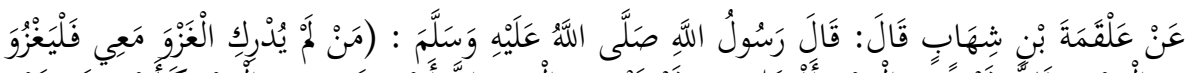

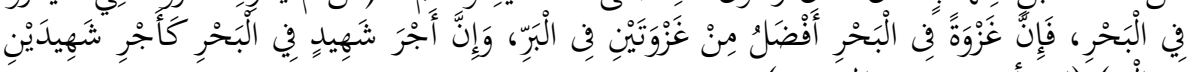

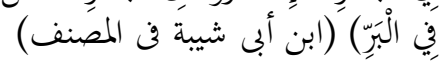

Alkame ibn Šihab kaže da je Allahov Poslanik, s.a.v.s., rekao: "Ko nije učestvovao u borbi sa mnom neka se bori na moru, jer jedna bitka na moru je poput dvije bitke na kopnu, jer zaista nagrada šehida na moru ima nagradu kao nagrada dvojice šehida na kopnu." ${ }^{66}$

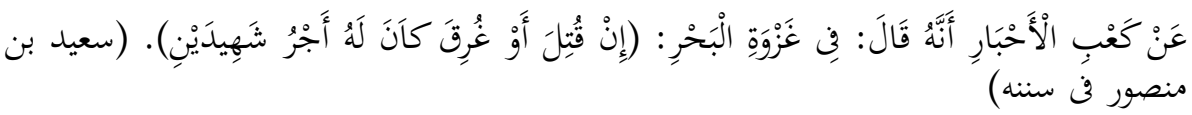

Ke'ab El-Ahbar je rekao o borbi na moru: "Ako bude ubijen ili se uguši imat će nagradu kao dva šehida." ${ }^{67}$

\section{Pohod bez ratnog plijena}

Ratni plijen je dozvoljen Muhammedovom, s.a.v.s., ummetu uz uvjet da se pravilno i onako kako je propisano raspodijeli. Kada se borci iz pohoda vrate bez ratnog plijena onda im se nagrada uduplava:

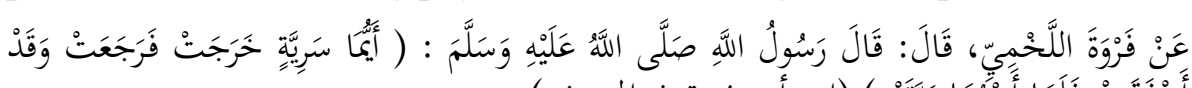

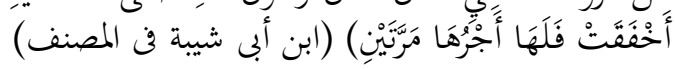

Ferve El-Lahmi, r.a., kaže da je Allahov Poslanik, s.a.v.s., rekao: "Kada god vojska izađe na Allahovom putu pa se vrati bez ratnog plijena imat će dublu nagradu." ${ }^{\text {" } 8}$

\section{Pogibija na Allahovom putu od vlastitog oružja}

Ako se borcu desi da nenamjerno pogine od svog vlastitog naoružanja i takav ima dvostruku nagradu:

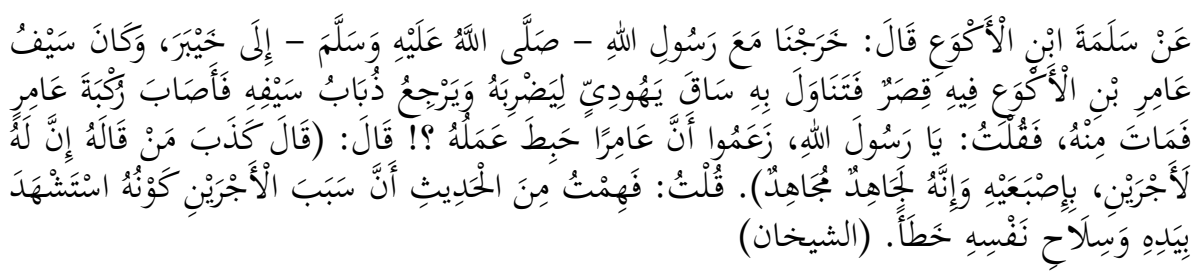

\footnotetext{
${ }^{66}$ Bilježi ga Ibn Ebi Šejbe u Musannefu.

${ }^{67}$ Bilježi ga Seid ibn Mensur u Sunenu.

${ }^{68}$ Bilježi ga Ibn Ebi Šejbe u Musannefu.
} 
Seleme ibn El-Ekve', r.a., je ispričao: -Krenuli smo sa Allahovim Poslanikom, s.a.v.s., prema Hajberu a sablja Amira ibn El-Ekve'a je bila kratka, pa kada je udario nekog židova po nozi oštrica sablje se odbila pa je potrefila Amirovo koljeno, te je zbog toga umro. Ja sam upitao: Allahov Poslaniče, neki smatraju da su Amirova dobra djela propala? On, s.a.v.s., reče: "Slagao je onaj ko tako kaže, on ima dvostruku nagradu -pokazujući sa dva prsta- jer se uistinu potrudio i borio." On reče: -Razumio sam iz hadisa da je razlog duple nagrade zbog toga što je postao šehid svojom rukom i svojim oružjem, nenamjerno. ${ }^{69}$

\section{Uvođenje lijepe prakse}

Ako uradimo neko dobro djelo kako bi se i drugi za nama u tome poveli imat ćemo dvostruku nagradu:

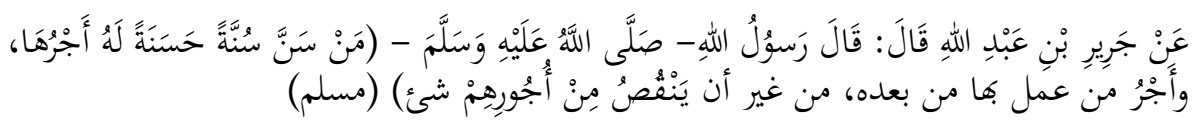

Džerir ibn Abdullah, r.a., prenosi da je Allahov Poslanik, s.a.v.s., rekao: "Ko uvede lijepu praksu ili postupak ima za to nagradu i nagradu svakog onoga ko bude to primjenjivao nakon njega, s tim što od njihove nagrade neće biti ništa umanjeno."

\section{Zadnji zeman/vrijeme}

S obzirom na iskušenja kroz koja će ljudi prolaziti spominje se da će u tim vremenima onaj ko se bude pridržavao vjerskih propisa imati veću nagradu nego oni koji su živjeli u vremenu bez takvih iskušenja:

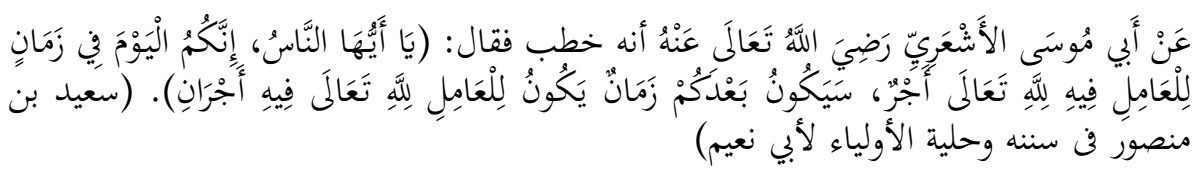

Jednom prilikom je Ebu Musa El-Eš'ari, r.a., držao hutbu pa je rekao: "O ljudi vi živite u vremenu kada onome koji radi u ime Allaha pripada

\footnotetext{
${ }^{69}$ Bilježe ga Buhari i Muslim.

${ }^{70}$ Bilježi ga Muslim.
} 
jedna nagrada a poslije vas će nastupiti vrijeme kada će onaj koji radi u ime Allaha imati dvostruku nagradu." ${ }^{71}$

\section{Kretanje ka hajru i pokornosti bez obuće}

Koliko se ko zahmeti i namuči u nekom poslu imat će veću nagradu. Tako je na primjer na hadžu veća nagrada onome koji dođe pješice od onoga koji dođe jašući i tome slično. Tako je i sa onim koji ide, u pokornosti i činjenju dobra, bez obuće $u$ odnosu na onoga koji ide $u$ obući:

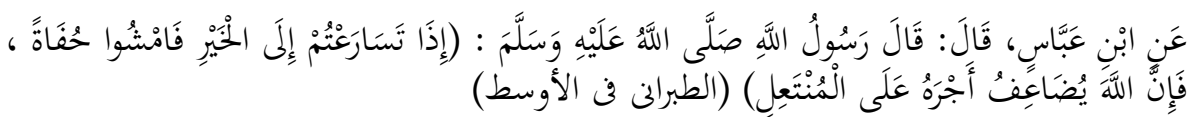

Ibn Abbas, r.a., prenosi da je Allahov Poslanik, s.a.v.s., rekao: "Kada se budete natjecali u nekom dobru onda idite bosi jer takvom Allah uistinu udvostručuje nagradu u odnosu na onoga ko je obuven." ${ }^{72}$

\section{Zaključak}

Na osnovu riječi Uzvišenog Allaha: "Onaj ko bude uradio koliko trun dobra - vidjet će ga, a onaj ko bude uradio i koliko trun zla - vidjet će ga," vjernik treba da bude svjestan svojih postupaka na ovom svijetu, koji je priprema za polaganje računa na Sudnjem danu. U islamu se svako dobro višestruko nagrađuje, pa čak i sam naum/nijjet da se uradi dobro djelo, biva nagrađen, pa makar i ne bilo urađeno to djelo. Međutim, kada se uradi, iskreno u ime Allaha i u skladu sa praksom Muhammeda, s.a.v.s., onda nagrada neće izostati i to višestruko, u čemu je i specifičnost vjere islama. Čak i osmjeh, ako je iskren, ima tretman sadake/udjeljivanja, pa šta je onda sa većim djelima koja vjernici u ime Allaha, dž.š., rade i ustrajavaju u njima. Najbolje je djelo ono u kojem se ustraje, pa makar ono bilo i beznačajano, naglašava Poslanik, s.a.v.s.

U prethodnom radu smo ukazali na specifičnost pojedinih djela, za koja njihovi počinioci bivaju dvostruko nagrađeni, bez obzira, bili ti počinioci muškarci ili žene, crni ili bijeli, bogati ili siromašni, jer su kod Allaha, dž.š., najpriznatiji oni koji su najbogobojazniji.

\footnotetext{
${ }^{71}$ Bilježe ga Seid ibn Mensur u Sunenu i Ebu Nuajm u El-Hil-ji.

${ }^{72}$ Bilježi ga Taberani u Evsatu, i ovaj hadis je vrlo slab.
} 
Molimo Allaha, dž.š., da naša djela učini iskrenim, da budu samo radi Njegovog zadovoljstva, da u njima ustrajemo i da za njih bude najljepše nagrađeni.

\section{Literatura na bosanskom jeziku}

1. Kur'an s prevodom, preveo Besim Korkut, Medina, 1412.h.g.

2. Tefsir Ibn-Kesir, skraćeno izdanje, Muhammed Nesib Er-Rifa'i, prijevod na bosanski - grupa prevodilaca, Visoki Saudijski komitet za pomoć BiH, Sarajevo, 2000-1420.h.g.

3. Rijadus-salihin, En-Nevevi, prijevod grupe prevodilaca na bosanski jezik, bez godine izdanja.

4. Sahihul-Buhari, Buharijeva zbirka hadisa, prvo cjelovito izdanje, VSK, Sarajevo, 2008.g.

5. Arapsko-bosanski riječnik, Teufik Muftić, Udruženje Ilmije u BiH, Sarajevo, 1973.

\section{Literatura na arapskom jeziku}

$$
\begin{aligned}
& \text { فهرس المصادر و المراجع: } \\
& \text { - - تفسير القرطبي، الجامع لأحكام القرآن، دار الحديث، القاهرة }
\end{aligned}
$$

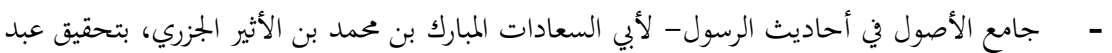

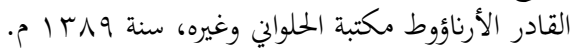

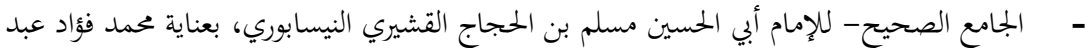

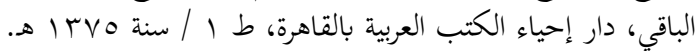

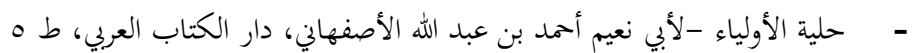

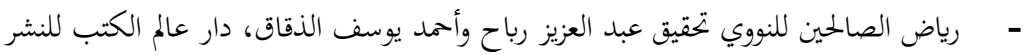

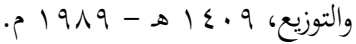

$$
\begin{aligned}
& \text { - - - - السنن للدارمي بتحقيق السيد عبد الله هاشم اليماني المدني. }
\end{aligned}
$$

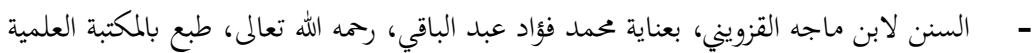

$$
\begin{aligned}
& \text { بيروت، لبنان. } \\
& \text { - }
\end{aligned}
$$

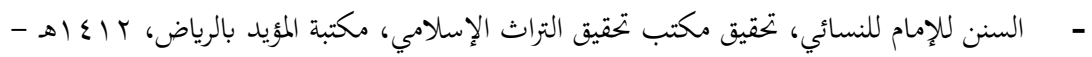

$$
\begin{aligned}
& \text {. r b/p199r } \\
& \text { - - شرح مسلم للنووي، دار المعرفة، بيروت لبنان، وطبعة محققة بإعداد خليل مأمون ط ام ا، } 0 \text { اعـ ا هـ } \\
& \text {. } 1990-
\end{aligned}
$$


شعب الإيمان، للبيهقي، دار الكتب العلمية، بيروت

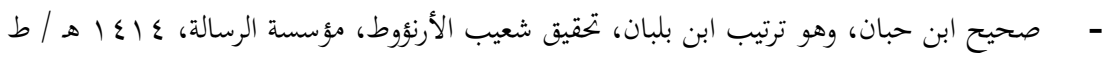
- احيح ابن خزيمة لأبي بكر محمد بن إسحاق بن خزيمة بتحقيق الأعظمي، المكتب الإسلامي،

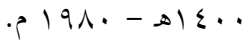
- عون المعبود شرح سن أبي داود لمحمد شمس الحق العظيم آبادي بتحقيق عبد الرممن محمد عثمان،

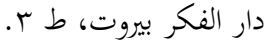

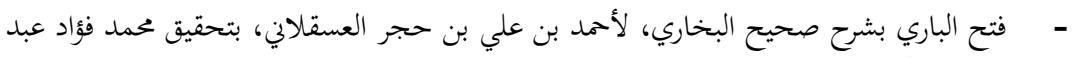
الباقي، مكتبة الرياض الحديثة.

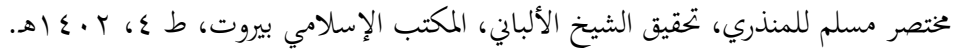

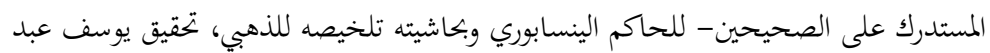
الرحمن، دار المعرفة بيروت.

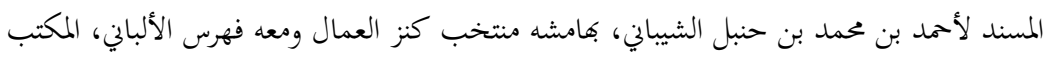
الإسلامي بيروت.

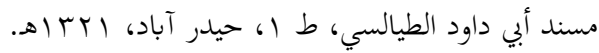

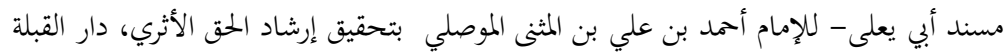
للثقافة، ط ا. مصنف ابن أبي شيبة، الدار السلفية

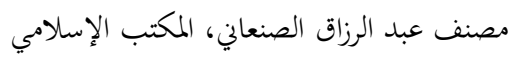

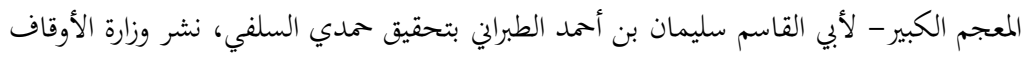
العراقية.

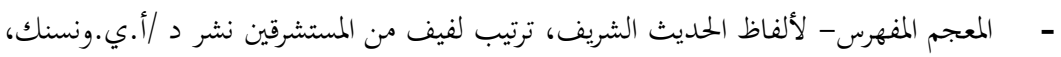

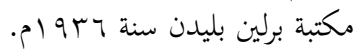
- - المعجم المفهرس - لألفاظ القرآن الكريم، للأستاذ معمد فؤاد عبد الباقي، المكتبة الإسلامية إستانبول. - - - المعجم الوسيط، مجمع اللغة العربية، المكتبة الإسلامية، إستانبول تركيا.

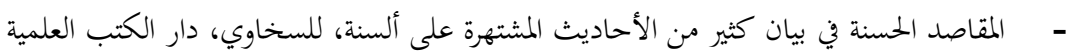

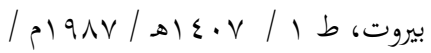
موارد الظمان إلى زوائد ابن حبان لنور الدين لإه الهيثمي، بتحقيق محمد بن عبد الرزاق حمزة، دار الكتب العلمية، بيروت.

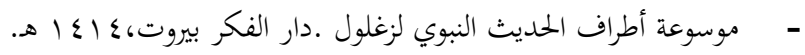

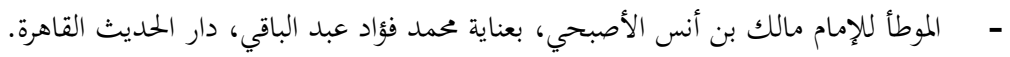




\section{Fuad Sedić, $\mathrm{PhD}$}

\section{PERSONS WHO WILL GET A DOUBLE AWARD}

\section{Abstract}

Every day a believer does and performs that what he was commanded and turns away from what is forbidden, because he longs for Allah's pleasure and Jannah. A part of Allah's mercy to His slaves is that deeds are multi-valued in Islam, so some deeds are rewarded ten times, some of them seventy times, and a prize for some deeds is known only to Allah.

This work aims to highlight the specificity of individual deeds and their doers who will be doubly rewarded, according to the texts from the Qur'an and Hadith.

Among these people are the followers of earlier heavenly Books who believe in Muhammad's, peace be upon him, mission; Muhammad's wives/ The Mothers of Believers; those who seek knowledge; reciter of the Qur'an that recites it with difficulty; one carefully listens to the Friday sermon (Khutba); the worshiper who prays on the left side of the mosque; the one who leads the congregation and Muezzins; the one who prayed with Tayammum, and repeats his Salah when he finds water, and others that are mentioned in the paper.

It is necessary to mention what the most famous commentators of the Quran said about the verses which deal with this subject, such as Ibn Kathir, alQurtubi and others, as well as to benefit from the most famous commentaries of Hadith collections, and scholars who have written on this subject, such as Imam Suyuti and others.

Keywords: double award, a believer, Jannah, twice, multiple awards 
الأستاذ الدكتور فؤاد سيديتش'

الأشخاص الذين سيحصلون على الأجر المضاعف

\section{الخلاصة}

رغبة في نيل رضا الله والجنة، فإن المؤمن يعمل وينفذ كل يوم ما هو مأمور باه ويجتنب من هو منهي عنه. من جملة رحمة الله عز وجل لعباده أن الأعمال في الإسلام يجازى عليها

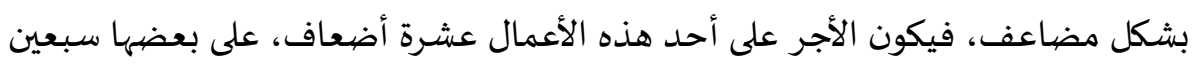

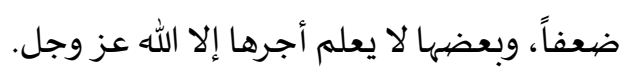
هدف البحث هو إبراز لمزايا بعض الأعمال وعامليها الذين سيحصلونها لاله وجله على الأجر

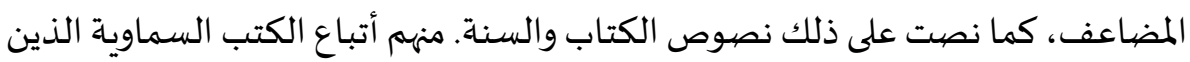

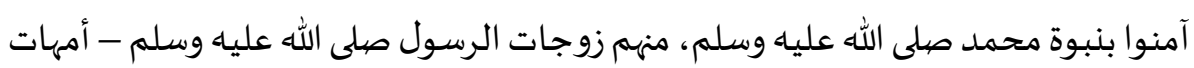

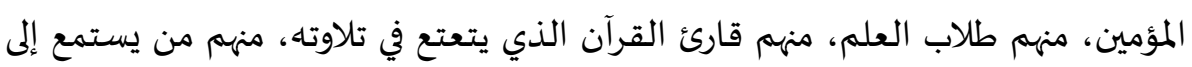

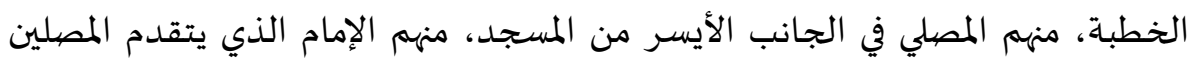

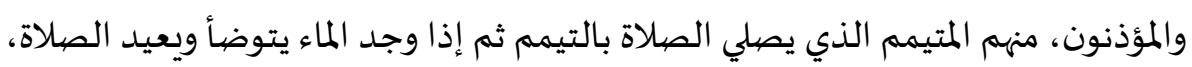
وغيرهم ممن ذكروا في هذا البحث.

لا شك أنه كان لا بد من إيراد ما ذكره المفسرون عند تفسير الآيات التي تتعلق بهذه

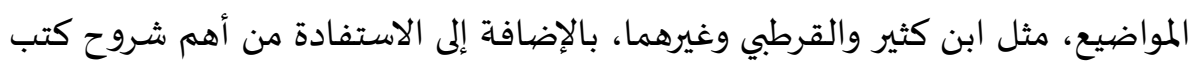
الحديث والعلماء الذين كتبوا حول هذا الموضوع، مثل الإمام السيوطي وغير وغيرها.

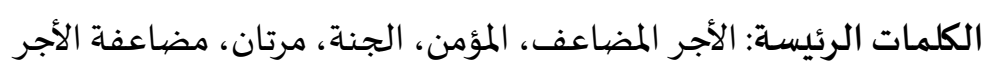

' الأستاذ وعميد كلية التربية الإسلامية في بيهاتش ' 